\title{
STUDI EVALUASI KONSELING OLEH KONSELOR SEBAYA DI PUSAT INFORMASI KONSELING REMAJA (PIK-REMAJA) PADA SLTA NEGERI KOTA BENGKULU
}

\author{
Ari Dwi Susilowati, Hadiwinarto, Arsyadani Mishbahuddin \\ Prodi Bimbingan dan Konseling Fakultas Keguruan dan Ilmu Pendidikan \\ Universitas Bengkulu \\ Aridewi717@yahoo.com,hadiwin@unib.ac.id,arsyadani@unib.ac.id
}

\begin{abstract}
ABSTRAK
Tujuan penelitian inimendeskripsikan evaluasi konseling oleh konselor sebaya di PIKRemaja SLTA Negeri Kota Bengkulu. Sampel dalam penelitian ini sebanyak 12 orang diambil menggunakan teknik purposive sampling dari seluruh konselor sebaya dan klien yang pernah melakukan konseling. Penelitian ini menggunakan desain penelitian evaluasi dengan pendekatan deskriptif kuantitatif. Sasaran evaluasi dalam penelitian ini adalah seluruh konselor sebaya. Instrumen yang digunakan dalam penelitian ini berupa kuesioner dan pedoman wawancara. Hasil kuesioner dihitung menggunakan skala ideal. Analisis data dilakukan dengan melakukan analisis deskriftif. Hasil penelitian yang dilakukan di PIKRemaja pada SLTA Negeri Kota Bengkulu, ketercapaian tujuan konseling oleh konselor sebaya diperoleh kategori sangat baik dengan nilai rata-rata sebesar 51, pelaksanaan tahapan konseling oleh konselor sebaya diperoleh kategorikan baik dengan nilai rata-rata sebesar 84, pelaksanaan prinsip-prinsip konseling oleh konselor sebaya diperoleh kategori baik dengan nilai rata-rata sebesar 39 dan pelaksanaan teknik konseling oleh konselor sebaya diperoleh kategori baik dengan nilai rata-rata sebesar 123,7.
\end{abstract}

Kata kunci: konselor sebaya, pik-remaja

\section{A STUDY OF CAUNSELING EVALUATION BY COEVAL COUNSELORS AT COUNSELING INFORMATION CENTER FOR TEENAGERS IN PUBLIC SENIOR HIGH SCHOOLS OF BENGKULU CITY}

\begin{abstract}
The aim of this study was to describe counseling evaluation by coeval counselors at Counseling Information Center for Teenagers on Public Senior High Schools of Bengkulu City. The samples in this study were as many as 12 people selected by using purposive sampling technique from all the coeval counselors and clients who previously have done counseling. This study used evaluation research guidance with qualitative descriptive approach. The evaluation target in this study was all the coeval counselors. The instruments used in this study were in the from of questionnaire and guided interview. The result of the questionnaire was calculated by using ideal scale. Data analysis was conducted by doing descriptive analysis. The results of the study conducted at Counseling Information Center for Teenagers on Public Senior High Schools of Bengkulu City showed that the achieved target of counseling by coeval counselors was in the very good category with the average score of 52, the implementation of counseling steps by coeval counselors was categorized as good with average score of 84 , the implementation of counseling principles by coeval counselors was categorized as good with the average score of 39 , and the implementation of counseling technique by coeval counselors was classified into good category with the average score of 123,7 .
\end{abstract}

Keywords: coeval counselors, counseling information center for teenagers 


\section{Pendahuluan}

Peran pendidikan sangat penting untuk menciptakan kader-kader muda yang memiliki kualitas yang baik. Bukan hanya dalam bidang akademik saja, akan tetapi memiliki sikap yang sesuai dengan normanorma yang berlaku dalam lingkungan keluarga, masyarakat, maupun di lingkungan teman sebaya. Melalui sarana pendidikan siswa mampu mengetahui dan mengembangkan potensi-potensi yang dimiliki, serta dapat menyalurkan bakat dan minat sesuai dengan keinginannya. Selain itu pendidikan juga sebagai wadah yang bertanggung jawab secara utuh, untuk mencerdaskan siswa agar menjadi pribadi yang mampu bertanggung jawab, bukan hanya kepada orang lain melainkan juga kepada diri sendiri (Permana, 2015:143).

Pendidikan bukan hanya diperoleh melalui jalur formal melainkandapat diperoleh melalui organisasi disekolah atau ekstra kulikuler. Salah satu kegiatan ekstra kulikuler yang menitikberatkan pada saat siswa mengikutipendidikan dalam menyiapkan diri untuk masa depan adalah Pusat Informasi dan Konseling Remaja (PIK-Remaja). PIK-Remaja adalah suatu wadah kegiatan program GENRE yang dikelola dari, oleh dan untuk remaja guna memberikan pelayanan informasi dan konseling tentang Perencanaan Kehidupan Berkeluarga Bagi Remaja serta kegiatankegiatan penunjang lainnya. PIK-Remaja adalah nama generik untuk menampung kebutuhan program GENRE dan menarik minat remaja datang ke PIK-Remaja. Nama generik ini dapat dikembangkan dengan nama-nama yang sesuai dengan kebutuhan program dan selera remaja setempat (BKKBN, 2013: 193).

Konselor sebaya merupakan pendidik sebayayang memiliki komitmen danmotivasi tinggi untuk memberikan konseling program generasi berencana (GenRe) bagiremaja dan telah mengikuti pelatihan konseling program generasi berencana (GenRe). Konselor sebaya bertugas sebagai konselor Pusat Informasi dan Konseling Remaja (PIK-Remaja) untuk menangani berbagai permasalahan remaja yang umum terjadi dilingkungannya (BKKBN, 2010:12).

Pelaksanaan layanan bimbingan dan konseling dapat berjalan dengan baik bila guru bimbingan dan konseling itu mampu berpikir secara kreatif dan bagaimana guru tersebut dapat menjadi sahabat bagi siswa. Melalui pendekatan yang baik, bersikap ramah dan terbuka kepada seluruh siswa maka anggapan yang baik dari siswa pun akan muncul. Namun masih ada saja 
persepsi yang keliru dan menganggap guru bimbingan dan konseling adalah sebagai polisi sekolah (Permana, 2015: 145).

Dengan adanya PIK-Remaja di setiap sekolah, guru bimbingan dan konseling dapat menggunakan organisasi siswa tersebut sebagai ujung tombak dalam mengatasi permasalahan remaja yang ada di setiap sekolah. Melalui konselor sebaya, guru bimbingan konseling dapat mengetahui apa saja permasalahan yang dihadapi siswa tanparasa takut dalam diri siswa karena remaja lebih cenderung leluasa menceritakan permasalahan yang dihadapinya kepada sesama sebayanya dibandingkan dengan orang yang lebih dewasa, terutama guruyang dianggapnya sebagai momok yang menakutkan (BKKBN, 2010: 15).

\section{Metode Penelitian}

Metode penelitian ini menggunakan desain penelitian evaluasi dengan pendekatan deskriptif kuantitatif untuk mengetahui pelaksanaan konseling sebaya di PIK-Remaja pada SLTA Negeri di Kota Bengkulu. Evaluasi merupakan suatu usaha mendapatkan berbagai informasi secara berkala, berkesinambungan dan menyeluruh tentang proses dan hasil dari perkembangan sikap dan perilaku, atau tugas-tugas perkembangan para siswa melalui program kegiatan yang telah dilakukan. Evaluasi bertujuan untuk mengetahui keterlaksanaan kegiatan dan ketercapaian tujuan dari program yang telah ditetapkan (Yusuf, 2009: 67).

Sasaran evaluasi dalam penelitian ini adalah seluruh konselor sebaya yang bertugas memberikan konseling pada remaja di PIK-Remaja pada SLTA Negeri di Kota Bengkulu yaitu SMA Negeri 5, SMA Negeri 2 dan MAN 1 Model. Model evaluasi yang dilakukan dalam penelitian ini adalah evaluasi model South Caroline dengan mengevaluasi konselor sebaya di PIK-Remaja pada SLTA Negeri di Kota Bengkulu untuk memastikan peningkatan kopetensi konselor sesuai tahapan umum konseling.

Evaluasi model South Caroline (Hadiwinarto, 2015: 24) berpendapat bahwa evaluasi merupakan komponen yang sangat penting dari sebuah program bimbingan dan konseling ke araha perkembangan komprehensif. Tujuan mengevaluasi konselor adalah untuk memastikan peningkatan kompetensi konselor yang berkelanjutan dalam program bimbingan dan konseling dan untuk memastikan program pelayanan terhadap siswa Evaluasi konselor, perlu adanya proses 
Proses evaluasi harus mencakup prinsipprinsip evaluasi secara tepat, mencerminkan teknik-teknik bimbingan yang efektif, keterampilan konseling, dan mencerminkan deskripsi kerja konselor sekolah (Hadiwinarto, 2015: 26).

Analisis data dalam penelitian ini adalah menggunakan analisis deskriftif yang bertujuan untuk menggambarkan pelaksanaan konseling yang dilakukan konselor sebaya di PIK-Remaja pada SLTA Negeri Kota Bengkulu. Setelah data diperoleh melalui kuesioner dan wawancara kemudian data dijabarkan dalam bentuk narasi (Sugiyono, 2014: 253).

\section{Hasil dan Pembahasan}

Analisis data ketercapaian tujuan konseling sebayadiperoleh hasil sebagai berikut:

Tabel 1. Data Ketercapaian Tujuan Konseling oleh Konselor Sebaya PIKRemaja pada SLTA Negeri Kota Bengkulu

\begin{tabular}{llll}
\hline PIK-Remaja & $\begin{array}{l}\text { Skor } \\
\text { Total }\end{array}$ & $\begin{array}{l}\text { Skor } \\
\text { Rata- } \\
\text { Rata }\end{array}$ \\
& \multicolumn{3}{c}{ Keterangan } \\
\hline SMA N 2 & 110 & 55 & Sangat Baik \\
\hline SMA N 5 & 92 & 46 & Baik \\
\hline MAN 1 Model & 102 & 51 & Sangat Baik \\
\hline Total & 304 & 51 & Sangat Baik
\end{tabular}

Sumber: data kuesioner 2017
Terlihat dari Tabel 1 bahwa nilai ratarata ketercapaian tujuan konseling oleh konselor sebaya di PIK-Remaja pada SLTA Negeri Kota Bengkulusebesar 51 dengan kategori sangat baik yang terdiri atasSMA Negeri 2 dengan kategori sangat baik, SMA Negeri 5 dengan kategori baik, dan MAN 1 Model dengan kategori sangat baik.

Analisis data tahapan konseling oleh konselor sebaya di PIK-Remaja SLTA Negeri Kota Bengkuludiperoleh hasil sebagai berikut:

Tabel 2. Data Pelaksanaan Tahapan Konseling oleh Konselor Sebaya di PIKRemaja pada SLTA Negeri Kota Bengkulu

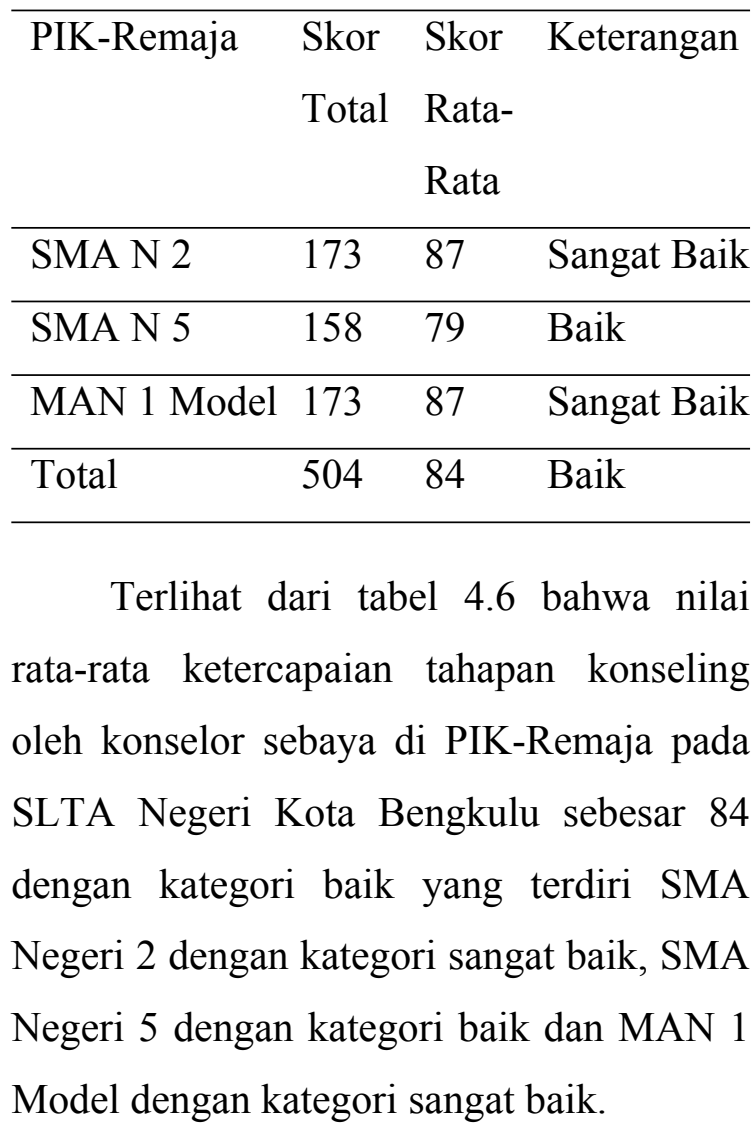


Analisis data prinsip-prinsip

konseling oleh konselor sebaya di PIKRemaja SLTA Negeri Kota Bengkulu diperoleh hasil sebagai berikut:

Tabel 3. Data Pelaksanaan Prinsip-Prinsip Konseling oleh Konselor Sebaya di PIKRemaja pada SLTA Negeri Kota Bengkulu

\begin{tabular}{llll}
\hline PIK-Remaja & Skor & Skor & Keterangan \\
& Total & Rata- \\
& & Rata \\
& & \\
\hline SMA N 2 & 80 & 40 & Baik \\
\hline SMA N 5 & 65 & 33 & Sedang \\
\hline MAN 1Model & 88 & 44 & Baik \\
\hline Total & 233 & 39 & Baik \\
\hline
\end{tabular}

Terlihat dari tabel 3 bahwa nilai ratarata ketercapaian prinsip-prinsip konseling oleh konselor sebaya di PIK-Remaja pada SLTA Negeri Kota Bengkulu sebesar 39 dengan kategori baik,yang terdiri atas SMA Negeri 2 dengan kategori baik, SMA Negeri 5 dengan kategori sedang dan MAN 1 Model dengan kategori sangat baik.

Analisis data diperoleh hasil teknik konseling oleh konselor sebaya di PIKRemaja SLTA Negeri Kota Bengkulu sebagai berikut:

Tabel 4. Data Pelaksanaan Teknik Konseling oleh Konselor Sebaya di PIKRemaja pada SLTA Negeri Kota Bengkulu

\begin{tabular}{ll}
\hline PIK-Remaja & Skor Skor Keterangan \\
& Total Rata-
\end{tabular}

\begin{tabular}{llll}
\hline & \multicolumn{2}{l}{ Rata } \\
\hline SMA N 2 & 249 & 124,5 & Baik \\
\hline SMA N 5 & 236 & 118 & Baik \\
\hline MAN 1 Mode & 257 & 128,5 & Sangat Baik \\
\hline Total & 742 & 123,7 & Baik \\
\hline
\end{tabular}

Terlihat dari tabel 4 bahwa nilai ratarata pelaksanan teknik konseling oleh konselor sebaya di PIK-Remaja pada SLTA Negeri Kota Bengkulu sebesar 123,7 dengan kategori baik yang terdiri atas SMA Negeri 2 dengan kategori baik, SMA Negeri 5 dengan kategori baik dan MAN 1 Model dengan kategori sangat baik.

Menurut Mcleod dalam Wahyuni (2014: 18-20), tujuan-tujuan konseling dilandasi oleh pondasi dari keragaman model teori dan tujuan sosial masingmasing pendekatan konseling. Berdasarkan hasil penelitian dengan melakukan penyebaran kuesioner pada 6 orang konselor sebaya dari masing-masing sekolah diperoleh nilai rata-rata ketercapaian tujuan konseling oleh konselorsebaya di PIK-Remaja SLTA Negeri Kota Bengkulu sebesar 51, artinya ketercapaian tujuan konseling sebaya dengan kategori baik.

Hasil penelitian ini didukung dengan hasil wawancara bahwa rata-rata responden yang melakukan koseling merasa lebih lega, 
lebih tenang, mendapatkan banyak pencerahan untuk memilih keputusan yang paling tepat dan merasakan beban yang dihadapi berkurang dan mendapatkan solusi dari masalah yang dia hadapi serta memahami materi program PIK-Remaja.

Berdasarkan hasil tersebut menunjukkan bahwa ketercapaian hasil konseling yang dilakukan konselor sesuai dengan apa yang dialami oleh klien. Menurut Abimanyu (1996: 13), tujuantujuan konseling secara lebih sederhana meliputi perubahan perilaku, kesehatan mental yang positif, pemecahan masalah, keefektifan pribadi dan pengambilan keputusan. Sedangkan menurutBKKBN (2013: 193) bahwa tujuan umum pusat informasi konseling remaja (PIK-Remaja) adalah untuk memberikan informasi GenRe (Generasi Berencana), Pendewasaan Usia Perkawinan (PUP), Keterampilan Hidup (Life skills), pelayanan konseling dan rujukan GenRe. Disamping itu, juga dikembangkan kegiatan-kegiatan lain yang khas dan sesuai minat dan kebutuhan remaja untuk mencapai tegar remaja dalam rangka tegar keluarga.

Menurut Burks dan Stefflre dalam Wahyuni (2014: 7), konseling merupakan hubungan profesional antara konselor terlatih dengan konseli. Hubungan ini biasanya bersifat individu ke individu, walaupun terkadang melibatkan lebih dari satu orang. Berdasarkan hasil penelitian dengan melakukan penyebaran kuesioner pada 6 orang konselor sebaya dari masingmasing sekolah diperoleh nilai rata-rata ketercapaian tahapan konseling oleh konselor sebaya di PIK-Remaja pada SLTA Negeri Kota Bengkulu sebesar 84, artinya ketercapaian tahapan konseling oleh konselor sebaya dengan kategori baik.

Hasil penelitian ini didukung hasil wawancara yang dilakukan pada klien yang pernah melakukan konselingmengatakan bahwa konselor menerima responden dengan ramah, terbuka, senyum yang hangat, baik dan bersahabat, konselor menjelaskan kontrak waktu ketika pada awal melakukan konseling, menjelaskan bahwa konseling adalah suatu wadah untuk membantu klien menyelesaikan masalahnya sendiri, klien harus bisa mandiri dan mampu mengambil keputusan sendiri, konselor menjelaskan tahapan konseling secara umum mulai dari perkenalan, inti dan penutup dengan klien hingga memberikan kesimpulan pada akhir konseling, konselor dan klien menetapkan masalah yang dialami oleh klien, dan mendiskusikan alternatif pemecahan masalah. 
Menurut Komalasari (2014: 27:29), pelaksanaan konseling sebaya di PIKRemaja sama seperti halnya konseling pada umumnya. Tahapan konseling secara umum yaitu meliputi tahap pengantaran (introduction), tahap penjajakan (investigation), tahap penafsiran (interpretation), tahap pembinaan (intervention) dan tahap penilaian (inspection).

Menurut Cavanagh dalam Komalasari (2014: 8) konseling merupakan hubungan antara helper (orang yang memberikan bantuan) yang telah mendapatkan pelatihan dengan orang yang mencari bantuan helpee (orang yang mendapat bantuan) yang didasari oleh keterampilan helper dan atmosfer yang diciptakan untuk membantu helpee belajar membangun relasi dengan dirinya dan orang lain dengan cara yang produktif (growth-producing).

Hasil penelitian dengan melakukan penyebaran kuesioner pada 6 orang konselor sebaya dari masing-masing sekolah diperoleh nilai rata-rata ketercapaian prinsip-prinsip konseling oleh konselorsebaya di PIK-Remaja pada SLTA Negeri Kota Bengkulu sebesar 39, artinya ketercapaian prinsip-prinsip konseling oleh konselorsebaya di PIK-Remaja pada SLTA
Negeri Kota Bengkulu dengan kategori baik.

Hasil penelitian ini didukung oleh hasil wawancara yang dilakukan pada klienyang pernah melakukan konseling mengatakan bahwa konselor menjelaskan masalah klien akan terjamin kerahasiaannya dan tidak boleh khawatir jika masalah akan terdengar keluar oleh orang lain sehingga klien diharuskan terbuka kepada konselor tanpa ada keragu-raguan, serta menjelaskan bahwa konseling akan di jadwalkan namun jika situasinya mendadak bisa menghubungi konselor secara langsung.

MenurutAbimanyu (1996: 20-24), prinsip-prinsip konseling yang dirumuskan oleh beberapa ahli diantaranya sasaran pelayanan konseling, masalah klien (individu), tujuan dan proses penanganan masalah atau pelaksanaan layanan, program pelayanan, dan penyelenggaraan pelayanan konseling di sekolah.

$$
\text { Komalasari (2014: }
$$

mendefinisikan konseling adalah suatu proses membantu individu untuk mengatasi masalah-masalahnya dalam perkembangan dan membantu mencapai perkembangan yang optimal menggunakan sumber-sumber dirinya.Hasil penelitian dengan melakukan penyebaran kuesioner kepada 6 orang konselor sebaya dari masing-masing 
sekolah diperoleh nilai rata-rata ketercapaian teknik konseling oleh konselor sebaya di PIK-Remaja pada SLTA Negeri Kota Bengkulu sebesar 123,7. Artinya, ketercapaian teknik konseling oleh konselorsebaya di PIK-Remaja pada SLTA Negeri Kota Bengkulu dengan kategori baik.

Hasil penelitian ini sejalan dengan penjelasan klien yang pernah melakukan konseling sebaya di PIK-Remaja SLTA Kota Bengkulu, bahwa konselor ada yang menggunakan teknik modelling, konselor memberikan penguatan kepada klien dengan meyakinkan klien untuk percaya diri, yakin bahwa klien mampu menyelesaikan masalahnya sendiri, harus lebih berani, memberikan pujian pada klien dan memberikan semangat kepada klien. Konselor menyimpulkan masalah dengan cara mengulang kembali apa yang menjadi permasalahan klien, keputusan klien dalam menyelesaikan masalah, memberikan alternatif pemecahan masalah pada klien. Konselor menutup konseling dengan mengevaluasi hasil konseling terlebih dahulu, menanyakan kembali bagaimana perasaan klien setelah melakukan konseling, memperbolehkan klien datang kembali kepada konselor jika ada hal-hal yang ingin diselesaikan lagi, mengucapkan terima kasih dan mengucapkan salam.

Menurut Mashudi (2012: 125-152), tehnik konseling dapat dibedakan menjadi teknik umum meliputi teknik Rapport, mengulang kembali (Restatement), Menerima (Acceptance), menstruktur (Structuring), memantulkan perasaan (reflection of feeling), klarifikasi (clarification), simpulan sementara (Summary), mendukung/penguatan, diam, konfrontasi, mengarahkan (directing), interpretasi, attending, empati, refleksi, eksplorasi, menangkap pesan (paraphrasing), pertanyaan terbuka (opened question), pertanyaan tertutup (closed question) dan dorongan minimal (minimal encouragement), sedangkan teknik khusus meliputi teknik latihan asertif, desensitisasi sistematis, pengkondisian aversi, pembentukan perilaku model, permainan dialog, latihan "saya bertanggung jawab atas", bermain proyeksi, teknik pembalikan, tetap pada perasaan, pemberian tugas rumah (home work assignment), imitasi, bermain peran dan teknik kursi kosong (empty chair).

Berdasarkan keseluruhan hasil penelitian evaluasi konseling oleh konselor sebaya di PIK-Remaja pada SLTA Kota Bengkulu sudah berjalan dengan baik. 
Keadaan tersebut juga didukung oleh sistem rekruitmen konselor sebaya yang dilakukan dengan berbagai tahapan di antaranya diawali dengan menjadi pendidik sebaya kemudian mengikuti pelatihan konselor sebaya, baru dilantik menjadi konselor sebaya sehingga diperoleh konselor yang baik. Selain rekruitmen konselor sebaya yang dijadikan responden berasal dariPIKRemaja unggulan di Kota Bengkulu sehingga diperoleh data pelaksanaan konseling oleh konselor sebaya yang baik.

\section{Kesimpulan}

Berdasarkan hasil penelitian yang telah dilakukan di PIK-Remaja pada SLTA Negeri Kota Bengkulu dapat disimpulkan hasil penelitian sebagai berikut:

1. Ketercapaian tujuan konseling oleh konselorsebaya yang dilakukan di PIKRemaja pada SLTA Negeri Kota Bengkulurata-rata $\quad$ sebesar 51 dikategorikan sangat baik.

2. Pelaksanaan tahapan konseling oleh konselorsebaya di PIK-Remaja pada SLTA Negeri Kota Bengkulurata-rata sebesar 84 dikategorikan baik.

3. Pelaksanaan prinsip-prinsip konseling oleh konselorsebaya di PIK-Remaja pada SLTA Negeri Kota Bengkulu rata-rata sebesar 39dikategorikan baik.

4. Pelaksanaan teknik konseling oleh konselorsebaya di PIK-Remaja pada SLTA Negeri Kota Bengkulurata-rata sebesar 123,7 dikategorikan baik.

\section{Daftar Pustaka}

Abimanyu. (1996). Teknik dan Laboratorium Konseling. Jakarta: Departemen Pendidikan dan Kebudayaan Direktorat Jenderal Pendidikan Tinggi

BKKBN. (2010). Kurikulum Diklat Teknis PengelolaanPIK-Remaja/Mahasiswa. Jakarta: Badan Kependudukan dan Keluarga Berencana Nasional Republik Indonesia

BKKBN. (2013). Pengelolaan PIK-R Dan $P I K-M$. Bengkulu: Badan Kependudukan dan Keluarga Berencana Nasional

BKKBN. (2013). Modul Pengembangan Program Generasi Berencana (Genre). Bengkulu: Badan Kependudukan dan Keluarga Berencana Nasional

Hadiwinarto. (2015). Evaluasi Akuntabilitas Bimbingan Dan Konseling. Bengkulu: Program Studi Bimbingan Dan Konseling FKIP Universitas Bengkulu

Komalasari, G. (2014).Teori Dan Teknik Konseling. Jakarta: Indeks

Mashudi, F. (2012). Psikologi Konseling: Buku Panduan Lengkap dan 
Praktis Menerapkan Psikologi

Konseling. Jogjakarta: IRCiSod

Permana, E. J. (2015). Pelaksanaan

Layanan Bimbingan Dan Konseling

Di Madrasah Aliyah Negeri 2

Banjarnegara. JurnalPendidikan.

Universitas Ahmad Dahlan. Vol.4, No. 2

Sugiyono, (2014). Metode Penelitian

Kualitatif dan $R \quad \& \quad D$.

Bandung:Alfabeta

Wahyuni,E. (2014). Teori dan Teknik

Konseling. Jakarta: Indeks

Yusuf, Samsu. (2009). Program Bimbingan dan Konseling di Sekolah. Bandung: Rizqi Pres 